\title{
Evaluation of Titania-Rich Slag Produced from Titaniferous Magnetite Under Fluxless Smelting Conditions
}

\author{
I.J. GELDENHUYS (i), ${ }^{1,3}$ Q.G. REYNOLDS,${ }^{1}$ and G. AKDOGAN ${ }^{2}$ \\ 1.-Mintek, Randburg, South Africa. 2.-Faculty of Engineering, Stellenbosch \\ University, Stellenbosch, South Africa. 3.—e-mail: isabelg@mintek.co.za
}

Titanium-bearing magnetite ore is generically defined as magnetite with $>1 \%$ titanium dioxide $\left(\mathrm{TiO}_{2}\right)$ and is usually vanadium-bearing. The iron and titanium occur as a mixture of magnetite $\left(\mathrm{Fe}_{3} \mathrm{O}_{4}\right)$ and ilmenite $\left(\mathrm{FeTiO}_{3}\right)$ with vanadium oxide usually occurring within the solid solution of the titaniumbearing magnetite phase. These ores are currently widely processed in blast furnaces via modified ironmaking processes. Typically, vanadium is recovered as a by-product from the ironmaking process, while the diluted titania slag is stockpiled. Fluxless smelting in a direct-current open-arc furnace is proposed as an opportunity to improve iron and vanadium recovery and potentially unlock the titanium as a slag product. Slags produced from a pilot study are compared to industrial slags produced from ilmenite. The findings from the pilot test show that slag produced under fluxless smelting conditions in an open-arc electric furnace is remarkably similar to industrial ilmenite slags. The test conditions were varied to evaluate the slag and metal composition, and furnace operation, under increasing reducing conditions. The study showed that the slag and metal product was remarkably similar to industrial slag produced from ilmenite.

\section{INTRODUCTION}

Fluxless smelting of ilmenite to produce furnace slag as feedstock for the pigment industry is a wellestablished industrial practice with extensive installed smelting capacity globally. ${ }^{1-4}$ Commercial ilmenite smelters produce two products, namely titania-rich slag and a pig iron by-product. In contrast, smelting practices for titaniferous magnetite (or titanomagnetite) recover only iron and vanadium. Vanadium is recovered as a by-product from the ironmaking process, while the titaniabearing slag is discarded as an inconvenient waste stream. In China it is said that about 90\% of Chinese titanium resources are associated with magnetite. ${ }^{5}$ Current practices treat these ores as a complex iron ore. The slag is modified by adding combinations of silica, limestone and even hematite ore to dilute the titania in the slag to overcome process constraints. In blast furnaces, for example,

(Received May 10, 2020; accepted July 22, 2020;

published online August 3, 2020) high-titania content in the slag can lead to severe operational challenges, such as blocking of tuyeres and hearth build-up due to excess formation of highly refractory titanium carbide phases. Present titanomagnetite processing practices result in large stockpiles of low-grade slags. Economically competitive methods to extract the residual value from the slag dumps have yet to be realised. Numerous technically feasible processes have been proposed, but as these slags are complex, low-grade and highly variable in composition, the economic viability of these proposed solutions is marginal at best. $^{6-9}$

Fluxless processing of titaniferous magnetite ores in an electric furnace is proposed as an opportunity to reduce the environmental impact of current titaniferous magnetite smelting practices and also improve overall metal recovery efficiencies. Unlocking the full potential of this complex ore is of economic interest, especially in China and South Africa, as both regions have large endowments of titaniferous magnetite and a history of processing these deposits for iron and vanadium recovery. ${ }^{10}$ To evaluate the potential of recovering titanium, it is 
crucial to evaluate the potential of titaniferous magnetite slag as a future feedstock for pigment production.

This article presents the results from a pilot-scale direct current (DC) furnace smelting test during which titaniferous magnetite ore was processed, in the absence of fluxes, to produce a titania-rich slag. The chemical compositions and general appearance of the slags from the pilot study are compared to those of industrial ilmenite smelters as part of establishing the potential of the proposed approach.

\section{BACKGROUND}

The titanium pigment industry is relatively young. Industrial pigment production emerged in the 1920s after titanium dioxide was first used as a pigment in 1908 when the French metallurgist A.J. Rossi mixed titanium dioxide with salad oil and brushed out the mixture. ${ }^{11,12}$ It is technically feasible to upgrade ilmenite directly via the sulphide or chloride process, but excessive waste streams would be generated. Smelting is the most effective way of upgrading iron-rich titaniferous ores. It is important to note that smelting offers only a minimal opportunity for the removal of minor impurities that may naturally be present in the titanium-bearing mineral, but it is possible to remove virtually all the iron through reductive smelting. The quality (and grade) of the feedstock determines the quality of the end product that can be produced. The co-production of iron is a significant economic and environmental advantage. About 30\% of the feedstock for the pigment industry is produced via smelting of ilmenite minerals in Canada and South Africa. ${ }^{13}$ Generally, feed materials with low concentrations of unwanted oxides are preferred, but naturally occurring high-grade materials are finite resources. ${ }^{13,14}$

Titaniferous magnetite (or titanomagnetite) deposits are well known to be numerous and significant in size. Titanomagnetite is generically defined as magnetite with $>1 \%$ titanium dioxide $\left(\mathrm{TiO}_{2}\right)$ and is usually vanadium-bearing. ${ }^{10,15}$ The iron and titanium occur as a mixture of magnetite $\left(\mathrm{Fe}_{3} \mathrm{O}_{4}\right)$ and ilmenite $\left(\mathrm{FeO} . \mathrm{TiO}_{2}\right)$. It is usual for the ilmenite and iron minerals to be intimately interlocked, limiting the clean separation of the magnetite and ilmenite via physical beneficiation Methods commonly associated with iron ore or beach sand deposits usually do not provide significant upgrading benefit because of the complex mineralisation of these ores. Fine grinding consequently does not quantitatively unlock the constituent minerals. ${ }^{16,17}$

As a result of the complex mineralogy and the physical variability, titanomagnetite ores are generally regarded as difficult to process, especially if compared to traditional iron ore or beach sand (containing ilmenite). Comprehensive utilisation of these ores thus requires the application of both physical and chemical methods.
The production of high-titania furnace slag is an iron removal step. Iron removal is achieved through the selective carbothermic reduction of iron oxide in the molten state, usually at temperatures of around $1650-1700^{\circ} \mathrm{C}$. The remaining oxides are proportionally concentrated in the slag, including the titania, resulting in slag typically containing $>80 \% \mathrm{TiO}_{2}$, but ranging from about $75-85 \% \mathrm{TiO}_{2}{ }^{18}$ The slag composition is dependent on the starting concentrations of the various oxides in the feedstock, the degree of iron reduction and the contribution of contaminants introduced during the smelting step. Ilmenite is intentionally processed in the absence of additives and contaminants (referred to as fluxless smelting in the context of this article). The iron extraction process offers little opportunity for removal of minor impurities that may naturally be present in the titanium-bearing mineral. ${ }^{19}$

\section{EXPERIMENTAL}

Pilot-plant smelting test work was conducted using Mintek's pilot DC electric arc furnace facility. Approximately 110 tons of concentrate, with an average $\mathrm{TiO}_{2}$ content of $35 \%$, was used to demonstrate the feasibility of smelting low-grade titaniferous ore in an open-arc DC smelter in the absence of fluxes.

\section{Description of the Pilot Furnace}

The pilot-plant furnace consists of a refractorylined cylindrical shell, a domed base, a conical roof and a refractory roof plug resting on top of the conical roof. The furnace, with a shell diameter of $2.5 \mathrm{~m}$, was lined with a magnesia-rich refractory brick. The installed refractory lining, approximately $230 \mathrm{~mm}$ in thickness, resulted in an average lined operating diameter (ID) of about $2 \mathrm{~m}$. An off-gas port (or opening), allowing for the extraction of process gasses, is located in the conical roof of the furnace. The shell has two openings, in which the taphole blocks are seated during the installation of the refractories. The conical roof and upper shell area are cooled through forced water-cooled circuits while the lower shell area is cooled with a film water-cooling system.

A single, prebaked graphite electrode located centrally to the furnace sidewalls serves as the cathode. The return electrode (or anode) consists of steel rods connected at their lower ends to a steel plate welded to the dome of the furnace. The anode pins are embedded in the magnesia-rich hearth refractory during installation. The roof contains two circular ports near the electrode port, one of which is utilised as a feed port while the second is generally used to inspect the furnace bath and take bath depth measurements by using a steel dip rod. The electrode clamp, roof and feed pipes are electrically isolated from the furnace. Auxiliary equipment includes a dedicated feed system, watercooling circuits, an off-gas handling system, which 
includes a bag filter plant, and an integrated control system. The description of the different aspects of the equipment as designed and used during the smelting test is briefly given for context. Figure 1 illustrates the general lay-out of the furnace during operation.

\section{Operational Methodology}

Slag and metal were removed from the furnace via dedicated slag and metal tapholes. Slag was tapped once the slag level in the furnace was deemed to consist of sufficient volume, typically at the end of a feeding cycle (or batch). A feeding cycle consisted of a predetermined mass of titania-bearing concentrate and reductant, fed concurrently at a set feeding rate that matches the desired power input to achieve the metallurgical objectives-referred to as the power-to-feed balance. A dedicated feed system, linked to a control system, is used to feed the desired recipe at the target rate. The batch duration is an outcome of the power-to-feed balance and a combination of inventory control and practical management of the tapping cycles. The typical batch size for the current project was about 2.2 tons of feed, fed over a period of between $2 \mathrm{~h}$ and $4 \mathrm{~h}$, depending on the targeted feed rate. During the

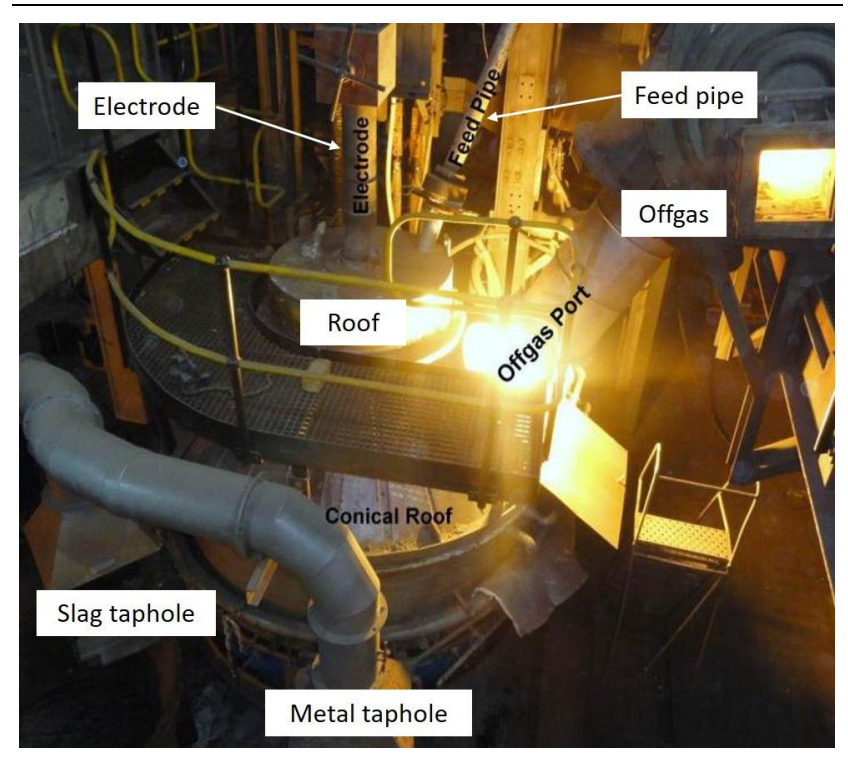

Fig. 1. Photograph of the pilot-plant furnace in operation with key elements annotated (photograph by author). removal of slag and metal from the furnace, a spoon sample method was used to sample the liquid stream, soon after the flow from the taphole was established: typically, a second and third sample was taken during the liquid extraction process.

\section{Raw Materials}

The concentrate smelted during the pilot trial was specially produced for the test, as the material originated from a Greenfield deposit that is not currently commercially mined. The as-received concentrate was blended before analyses-composite samples were prepared for purposes of characterising the bulk sample and for mass balance purposes. The bulk chemical composition of the titanomagnetite concentrate is summarised in Table I. Total $\mathrm{Fe}$ and $\mathrm{Ti}$ are expressed as $\mathrm{FeO}$ and $\mathrm{TiO}_{2}$ as a choice of convention.

The oxidation state of $\mathrm{Fe}$, specifically $\mathrm{Fe}^{2+}$ and $\mathrm{Fe}^{0}$, was analysed, while $\mathrm{Fe}^{3+}$ was calculated by difference. The average ratio of $\mathrm{Fe}^{2+} / \mathrm{Fe}^{3+}$ for the sample as tested was 1.7. A volatile component associated with the presence of clay minerals, approximately $0.5 \%$, was noted. The average moisture content of the titaniferous concentrate was approximately $5 \%$. The moisture content of the finely sized material was not ideal, but it was not practical to undertake bulk drying of the fine feed material prior to the test. Moisture during smelting contributes to increased energy consumption as well as increased off-gas volumes. The high moisture content did not however adversely impact the metallurgical outcomes of the smelting campaign but did increase the overall energy consumption.

The typical appearance of the titanomagnetite and ilmenite phases is illustrated by the backscattered electron image in Fig. 2; the appearance is very typical of titaniferous magnetite deposits. ${ }^{16,20,21}$

A low-ash reductant was used to minimise the potential for ash from the reductant to contaminate the slag during smelting. It is usual for ilmenite smelters to select low-ash reductants to minimise diluting the final product, the slag. The reductant used during the pilot test consisted of $79 \%$ fixed carbon, $11 \%$ volatiles and $8.6 \%$ ash with low concentrations of both $\mathrm{S}$ and $\mathrm{P}(<0.01 \%)$. The ash composition was found to mainly consist of iron, reported as $\mathrm{FeO}$ (about $83 \%$ of the ash), with minor

Table I. Average bulk chemical analysis of titaniferous magnetite concentrate, mass\%

\begin{tabular}{|c|c|c|c|c|c|c|c|c|c|}
\hline FeO & $\mathbf{T i O}_{2}$ & MgO & $\mathbf{A l}_{2} \mathbf{O}_{3}$ & $\mathrm{SiO}_{2}$ & $\mathrm{CaO}$ & $\mathbf{V}_{2} \mathbf{O}_{5}$ & $\mathrm{Cr}_{2} \mathrm{O}_{3}$ & MnO & Total \\
\hline 55.15 & 35.50 & 0.68 & 1.23 & 1.06 & $<0.05$ & 0.44 & 0.08 & 0.59 & 94.7 \\
\hline
\end{tabular}

LOI (dry basis, under argon) 0.5\%, S 0.01\%, C 0.05\%, P $166 \mathrm{ppm}, \mathrm{U}$ and Th $<10 \mathrm{ppm}$. Particle size: $95 \%$ of the feed $<300 \mu \mathrm{m}$, with a D50 of $120 \mu \mathrm{m}$. 


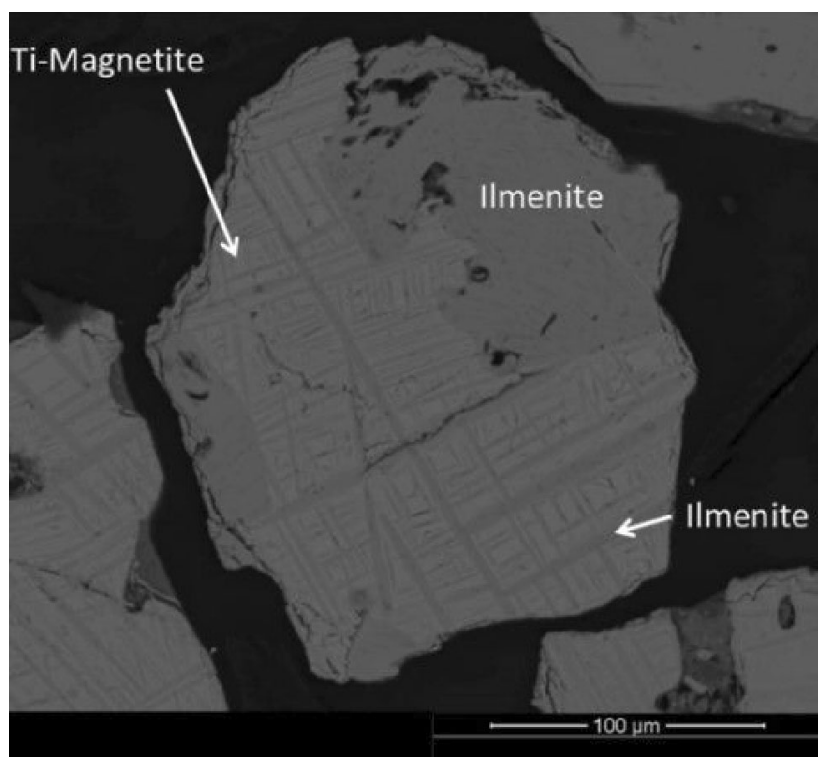

Fig. 2. Backscattered electron image of the texture of magnetite showing a typical mixture of titanomagnetite and ilmenite.

Table II. Overall material balance for the pilot study, feed and product masses, $\mathrm{kg}$

\begin{tabular}{lcccc}
\hline Feed & & & \multicolumn{2}{c}{ Products } \\
\hline $\begin{array}{l}\text { Start-up heel } \\
\text { (mild steel) }\end{array}$ & 1100 & & Slag & 40,326 \\
$\begin{array}{l}\text { Concentrate, } \\
\text { dry basis }\end{array}$ & 102,126 & & Metal & 46,705 \\
$\begin{array}{l}\text { Reductant (ash) } \\
\text { Total feed }\end{array}$ & 1727 & & Off-gas dust & 6431 \\
\hline
\end{tabular}

contributions from $\mathrm{MgO}, \mathrm{Al}_{2} \mathrm{O}_{3}, \mathrm{CaO}$ and $\mathrm{SiO}_{2}$ making up the difference.

\section{RESULTS AND DISCUSSION}

The main objective of the smelting test was to demonstrate the feasibility of producing slag from titaniferous magnetite via fluxless smelting. The pilot furnace was continuously operated for 15 days. The operation resembles that of an industrial furnace operation.

Table II summarises the overall material balance for the project during which titaniferous magnetite concentrate was smelted to produce slag and metal. The material balance excludes moisture from the concentrate and $\mathrm{C}$ from the reductant and graphite electrodes, and only solid products were collected and weighed. Solids (slag, metal and dust) recovered from the furnace during excavation are included.

Approximately $495 \mathrm{~kg}$ of graphite electrode was consumed during the test campaign, a consumption rate of about $1.4 \mathrm{~kg}$ graphite per $\mathrm{MWh}$, which is typical for the scale and open-arc operation.
After the furnace was ramped up from cold, a period of stabilisation followed during which minor adjustments to the recipe and operating conditions were made until a suitable stable operating regime could be maintained. Anthracite addition was systematically increased during the smelting campaign to evaluate the operability of the process under increasingly reducing conditions.

Table III summarises key parameters for the four main operating periods. During start-up and stabilisation, adjustments to the operation aims to achieve metallurgical stability while heating up the furnace refractories, and the outcomes are usually excluded from the metallurgical review. The stable operating periods achieved after the initial start-up periods are used as the primary metallurgical results for the current study as adjustments to the operating conditions are minimised.

A good-quality iron product with low levels of unwanted elements was produced during the pilot test. The average composition of the metal produced during the stable operating period is presented in Table IV.

Figure 3 presents the evolution of $\mathrm{FeO}$ (Fig. 3a) and $\mathrm{TiO}_{2}$ (Fig. 3b) for the duration of the test. The graphs represent the evolution of the pilot test via the two main slag components, showing a high degree of stability was achieved after the start-up and stabilisation conditions. The stable operating conditions were maintained for substantial periods (indicated in Fig. 3 via dashed lines). High furnace availability (minimal operational interruption) and metallurgical stability are essential to ensure that the pilot smelting results resemble industrial conditions as closely as possible. The average slag composition for two of the operating periods, namely batch 25-32 and batch $33-51$, is presented in Table V; these periods represents the most stable operating conditions.

With increased reduction, $\mathrm{FeO}$ content in the slag decreased, and the $\mathrm{TiO}_{2}$ content in the slag increased relative to residual $\mathrm{Fe}$ content of the slag. As the residual $\mathrm{FeO}$ decreased to very low levels, slag viscosity increased, as expected, ${ }^{22}$ and the operation temperature was adjusted to ensure slag flowed from furnace. The operating temperature was not optimised because of time and material constraints. The average slag tapping temperature was about $1780^{\circ} \mathrm{C}$ for slags with $\mathrm{FeO}$ concentrations $<4 \%$. Although it is possible to virtually reduce all the iron oxide from the slag, consequences include: a dramatic increase in slag viscosity, energy consumption and operational challenges. ${ }^{23}$

As iron is removed from the slag via reduction, the remaining components, dominated by the $\mathrm{TiO}_{2}$, are proportionally upgraded. The proportional upgrade of $\mathrm{TiO}_{2}$ as a function of $\mathrm{FeO}$ reduction (residual $\mathrm{FeO}$ in the slag as proxy) is expected to be linear. The linear trend plot for $\mathrm{TiO}_{2}$ in slag as a 
Table III. Operational summary for distinct operating periods

Batches in the period

Number of batches in period Duration of the period Average operating power Average operating voltage Gross energy input

Feed masses

Concentrate (as fed)

Average anthracite addition

Product masses

Slag tapped

Metal tapped

Dust collected (overall)

\begin{tabular}{|c|c|c|c|c|}
\hline $\begin{array}{c}\text { Start-up } \\
1-6\end{array}$ & $\begin{array}{c}\text { Stabilisation } \\
7-24\end{array}$ & $\begin{array}{c}\text { Period } 1 \\
\text { 25-32 }\end{array}$ & $\begin{array}{c}\text { Period } 2 \\
\text { 33-51 }\end{array}$ & $\begin{array}{c}\text { Overall } \\
1-53\end{array}$ \\
\hline 6 & 18 & 8 & 19 & 53 \\
\hline 87.2 & 102.5 & 52.0 & 117.7 & 379.0 \\
\hline 800 & 1200 & 1200 & 1300 & 1200 \\
\hline 218 & 230 & 250 & 250 & 240 \\
\hline 53.5 & 51.7 & 52.2 & 119.3 & 343.6 \\
\hline 15.8 & 30.4 & 16.5 & 38.9 & 107.5 \\
\hline 14.6 & 18.4 & 20.0 & 19.5 & 18.6 \\
\hline 5.3 & 12.7 & 4.1 & 12.7 & 40.3 \\
\hline 4.3 & 12.4 & 7.6 & 16.1 & $\begin{array}{r}46.7 \\
5.9\end{array}$ \\
\hline
\end{tabular}

Table IV. Weighted average analysis and standard deviation of the metal produced from batch $25-51$, mass $\%$

\begin{tabular}{|c|c|c|c|c|c|c|c|c|c|}
\hline & $\mathbf{F e}$ & Si & $\mathbf{T i}$ & $\mathbf{V}$ & $\mathbf{C r}$ & Mn & $\mathbf{C}$ & $\mathbf{P}$ & $\mathbf{S}$ \\
\hline \multicolumn{10}{|l|}{ Batch 25-51 } \\
\hline Average & 96.2 & 0.21 & 0.09 & 0.37 & 0.03 & 0.08 & 2.87 & 0.02 & 0.01 \\
\hline$\sigma$ & 0.42 & 0.22 & 0.10 & 0.15 & 0.01 & 0.04 & 0.40 & - & - \\
\hline
\end{tabular}
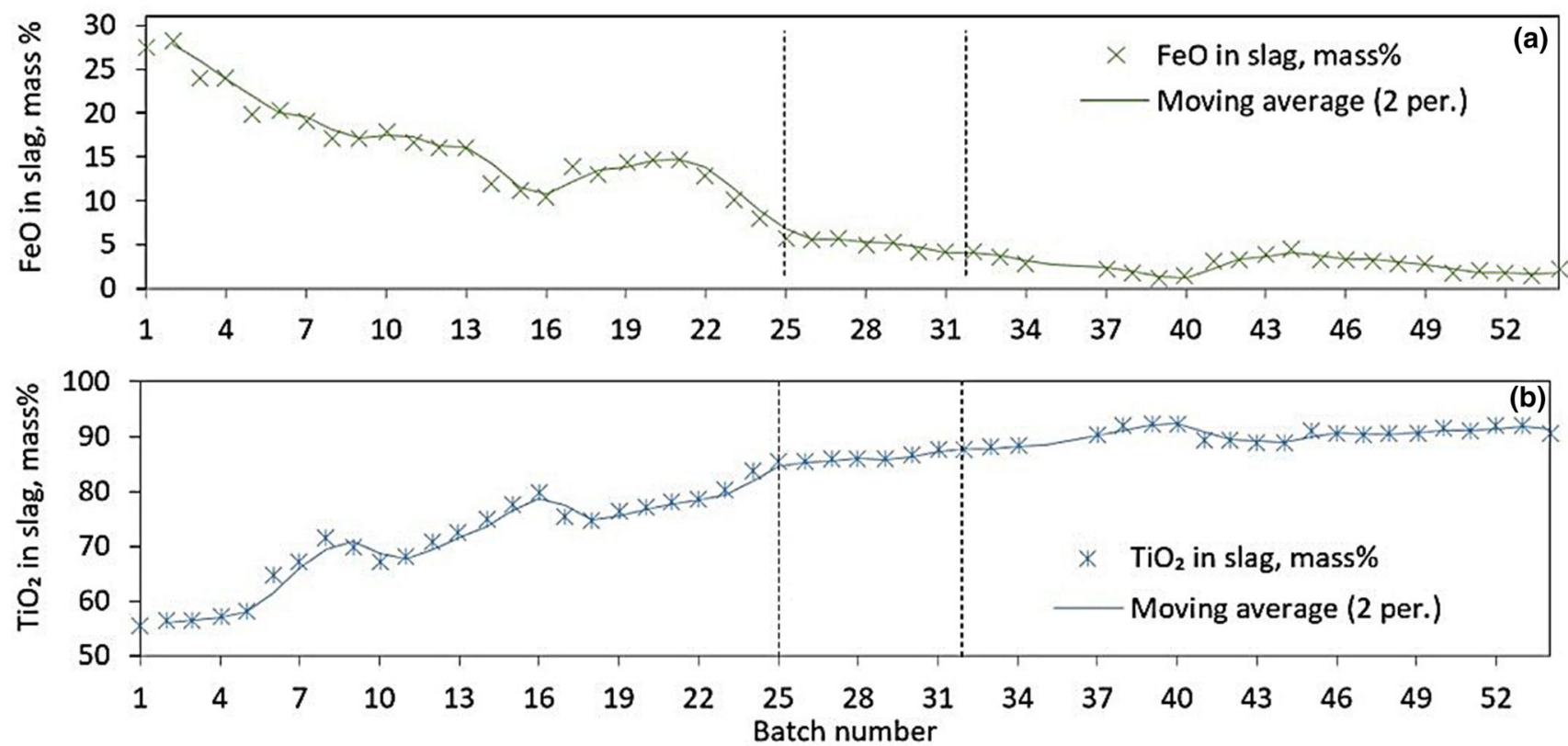

Fig. 3. Evolution of $\mathrm{TiO}_{2}$ (a) of $\mathrm{FeO}(\mathrm{b})$ in the slag for the pilot test, mass\%.

function of residual $\mathrm{FeO}$ is shown in Fig. 4. Most impurities from the titaniferous ore are expected to report to the slag phase. There is little or no scope to decrease impurity levels in slag during smelting, while there are ample ways to dilute the product via additives and refractory wear.
During the pilot test, slag dilution was intentionally minimised by not adding any fluxes, minimising unnecessary contamination from the reductant ash, and finally via careful control of the power and feed balance during operation to minimise refractory wear in an effort to maximise the upgrade. As a 
Table V. Weighted average and standard deviation on slag analyses for two stable operating periods, mass $\%$

\begin{tabular}{|c|c|c|c|c|c|c|c|c|c|}
\hline & MgO & $\mathbf{A l}_{\mathbf{2}} \mathbf{O}_{3}$ & $\mathrm{SiO}_{2}$ & $\mathrm{CaO}$ & $\mathrm{TiO}_{2}$ & $\mathbf{V}_{2} \mathbf{O}_{5}$ & $\mathrm{Cr}_{2} \mathrm{O}_{3}$ & MnO & $\mathrm{FeO}$ \\
\hline \multicolumn{10}{|l|}{ Batch 25-32 } \\
\hline Average & 4.09 & 3.59 & 2.40 & 0.17 & 86.19 & 0.91 & 0.15 & 1.26 & 5.08 \\
\hline $\begin{array}{l}\sigma \\
\text { Batch } 33-51\end{array}$ & 0.56 & 0.10 & 0.19 & 0.00 & 0.95 & 0.06 & 0.02 & 0.19 & 0.76 \\
\hline Average & 3.25 & 3.71 & 1.84 & 0.17 & 90.39 & 0.58 & 0.09 & 0.76 & 2.58 \\
\hline$\sigma$ & 0.62 & 0.17 & 0.35 & 0.01 & 1.33 & 0.13 & 0.02 & 0.13 & 0.93 \\
\hline
\end{tabular}

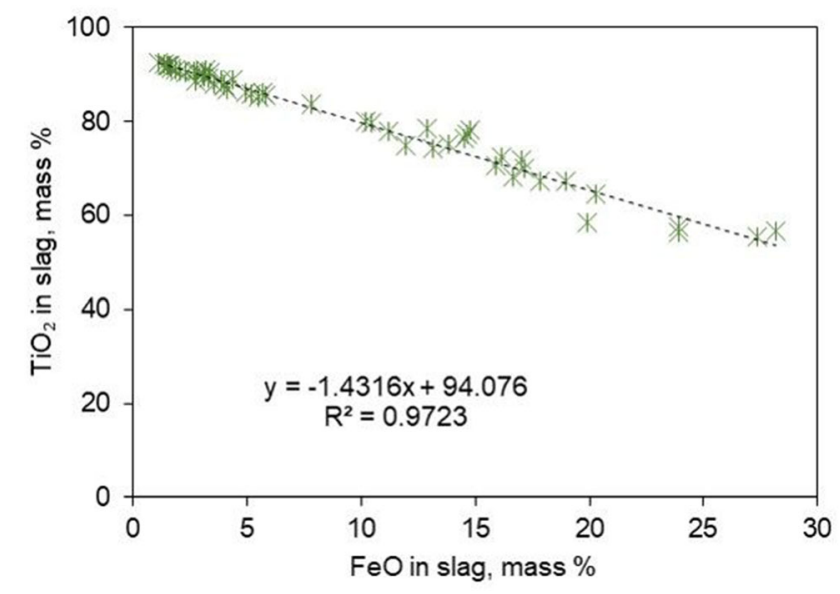

Fig. 4. $\mathrm{TiO}_{2}$ in the slag as a function of the residual $\mathrm{FeO}$ content, mass $\%$.

result, the slag upgraded proportionally with increased iron reduction, in line with expected trends.

\section{Phase Chemical Evaluation of Selected Slag and Metal Samples}

During the smelting test, samples of slag and metal were collected for subsequent phase-chemical investigation, representing periods with metallurgical and operational stability. The slag samples were water-quenched by directly pouring liquid slag, sampled during tapping, into a drum of water with an air bubbler installed in the bottom.

The quenched samples were examined through a combination of x-ray diffraction (XRD), scanning electron microscopy (SEM) and electron microprobe analysis (EMPA). SEM-based energy-dispersive spectrometry (EDS) microanalysis was used to gain a broad-phase chemical understanding of the phases present. EMPA-based wavelength dispersive spectrometry (WDS) analysis of the main titaniumbearing phase was conducted to more accurately determine the composition of the titanium-bearing phase. The investigation aimed at determining whether the phase chemistry of the slags from the pilot test differs significantly from industrial furnace slags produced from ilmenite smelting. SEMbased (EDS) microanalysis was used to identify the main metal phases and determine if any inclusions were present. EMPA-based (WDS) analysis of the
Fe-bearing phase was used to determine the composition of this phase more accurately.

\section{Phase-Chemical Assessment of the Slag}

Figure 5 shows the general appearance of the slag from the pilot plant via backscattered electron micrographs; both slag examples were produced during the metallurgically stable period. The micrographs confirm the presence of a dominant $\mathrm{M}_{3} \mathrm{O}_{5}$ phase and small amounts of interstitial liquid silicate. The dominance of the $\mathrm{M}_{3} \mathrm{O}_{5}$ phase is not unexpected for the slag system. ${ }^{24}$ Small entrained metal droplets $(<10 \mu \mathrm{m})$ are also observed. The tiny droplets consist of high-purity metallic iron and are usually located at the grain boundaries of the main phase embedded in the silicate glassy phase. The findings are consistent with observations regarding the phase chemistry of high-titania slags from Sorel in Canada, as described by Guéguin and Cardarelli, ${ }^{21}$ including the location and size of the metallic droplets.

Titanium can exist in two oxidation states in the $\mathrm{M}_{3} \mathrm{O}_{5}$ phase, namely as $\mathrm{Ti}^{4+}$ (e.g. $\mathrm{TiO}_{2}$ ) and $\mathrm{Ti}^{3+}$ (e.g. $\mathrm{Ti}_{2} \mathrm{O}_{3}$ ). The analytical techniques employed do not distinguish between these two states and as a result reported totals for the $\mathrm{M}_{3} \mathrm{O}_{5}$ phase can exceed $100 \%$. The average WDS analysis of the $\mathrm{M}_{3} \mathrm{O}_{5}$ phase for the slag samples evaluated is presented in Table VI together with the bulk composition of the samples. The $\mathrm{M}_{3} \mathrm{O}_{5}$ phase contains remarkably low levels of $\mathrm{FeO}$, which is consistent with the average bulk chemical composition of the slag during this period. The low $\mathrm{FeO}$ concentrations in the pilot test slag confirm that relatively reducing conditions existed in the furnace. As a result, the major impurities in the slag are $\mathrm{MgO}, \mathrm{Al}_{2} \mathrm{O}_{3}$ and $\mathrm{SiO}_{2}$; typically, $\mathrm{FeO}$ is the major impurity in high-titania slags from ilmenite smelting. Due to the highly reducing conditions, the expected dominant titania-bearing phase is $\mathrm{Ti}_{2} \mathrm{O}_{3}$; however, it appears that the presence of $\mathrm{MgO}$ as an impurity to some extent stabilised the $\mathrm{M}_{3} \mathrm{O}_{5}$ phase. Titanium oxy-carbide phases were not observed in the slags (a by-product of over-reduction observed in high-titania slags). Tiny metal droplets with similar appearances as typical industrial slags were detected. ${ }^{21}$

The slags produced from low-grade titaniferous magnetite were found to generally be similar in appearance to slag produced from more typical 

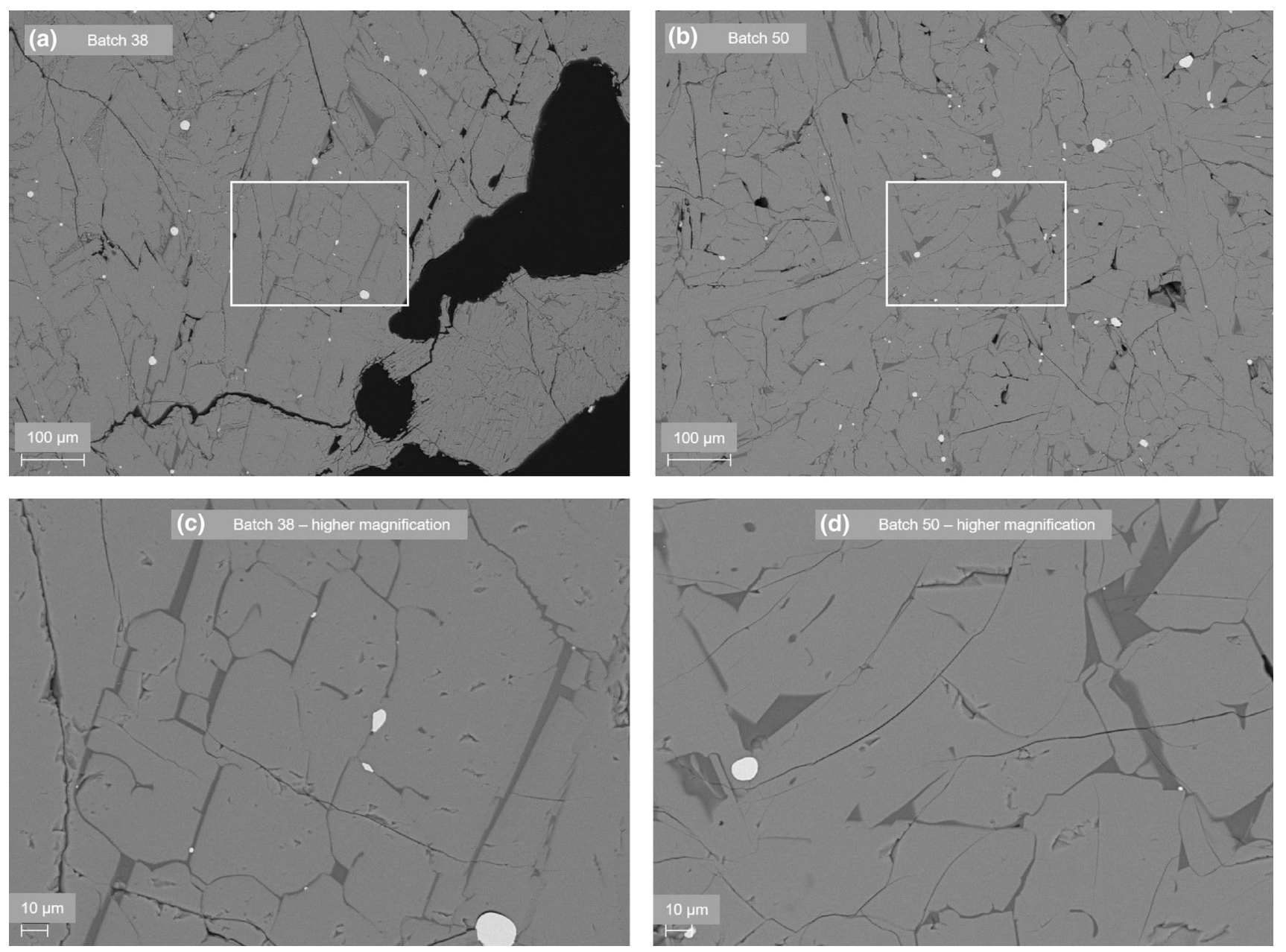

Fig. 5. General appearance of slag from batch 38 and $50(a, b)$ showing the presence of $\mathrm{M}_{3} \mathrm{O}_{5}$ (dominant phase) and interstitial silicate (dark grey phase) and the presence of small metallic droplets at the boundaries of the main phase embedded in the silicate phase (higher magnification of highlighted zones via $\mathrm{c}$ and $\mathrm{d}$ ).

ilmenite feedstock, and there appears to be some benefit regarding the opportunity to operate with lower levels of $\mathrm{FeO}$ (which results in higher $\mathrm{Fe}$ recovery), which warrants further investigation.

\section{Phase-Chemical Assessment of the Metal Product}

SEM-based analysis determined that the metal consisted of two phases, namely a dominant Femetal phase and a C-bearing Fe-metal phase. Table VII presents the results of the microanalysis of the two phases; the bulk chemical compositions of the samples are included for reference. The three metal samples, from three different periods in the test, were selected to assess the impact of increased reduction on the quality of the metal product. The composition of the metal phases corresponds well with the bulk chemical composition. The low concentration of $\mathrm{Ti}$ suggests that Ti-bearing inclusions are not present in the metal. In general, few inclusions were observed in the metal samples, an excellent outcome with respect to the quality of the metal product. Overall, it can be concluded that despite highly reducing conditions, the metal product quality did not appear to deteriorate significantly and the vanadium was confirmed to partition to the metal phase.

\section{SUITABILITY AND OPPORTUNITY FOR TITANIFEROUS MAGNETITE SLAGS}

The phase chemical investigation of the slag produced during the pilot test determined that the phase chemistry of the pilot plant slags did not differ significantly from typical high-titania furnace slags produced from ilmenite feedstocks. The results show that the slag has the same appearance as typical ilmenite furnace slag, especially the slags produced at the Sorel site. The Sorel process includes various upgrading stages prior to smelting and is an excellent example of an appropriate effort that may be suitable for titaniferous magnetite ore, not usually amenable to normal physical upgrading processes. At Sorel, a roasting stage (thermal treatment of the ore after physical upgrading) prior to smelting achieves an upgrade from $34 \%$ to $37 \%$ 

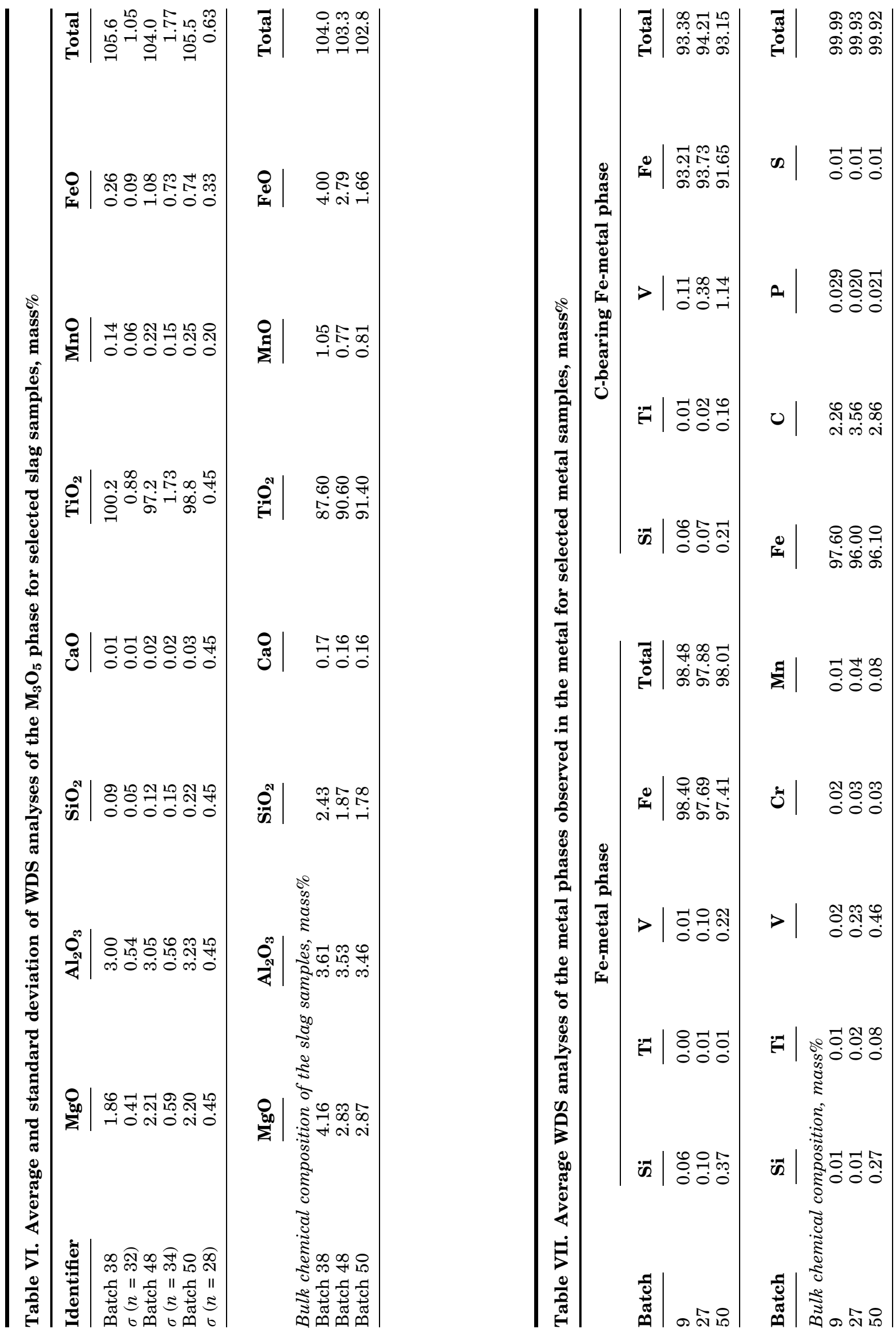
$\mathrm{TiO}_{2}$, lowering the total $\mathrm{SiO}_{2}$ and $\mathrm{Al}_{2} \mathrm{O}_{3}$ content. ${ }^{21}$ As current titanomagnetite smelting practices focus on minimising titania content, there may be scope to increase the titania grade of these ores with simple interventions. Instead of thinking of these ores as a complex iron ore, it may be beneficial to instead focus on upgrading the titania content, that is, treating the ores as a titania feedstock.

The Sorel plant addresses the $\mathrm{SiO}_{2}, \mathrm{MgO}$ and $\mathrm{CaO}$ contents of the standard furnace slag producing an upgraded slag (UGS) product. The upgrade is achieved by grinding and sizing the slag, followed by roasting to produce heat-treated slag to aid the subsequent leaching of the impurities. Leaching is carried out with hydrochloric acid and results in a product containing 92-95\% $\mathrm{TiO}_{2} \cdot{ }^{25}$ Removal of the $\mathrm{MgO}$ and $\mathrm{CaO}$ is critical to creating a product suitable for use in the chloride pigment plants. The pilot study demonstrated that the titaniferous magnetite slags produced from the pilot test are very similar to slags produced from ilmenite, and it is therefore likely that these slags can be upgraded using a similar process. The smelting process normalises the slags resulting in a high degree of similarity, regardless of the origin or complexity. The composition of the impurities in titaniferous magnetite may offer some advantages for downstream upgrading and purification processes. The higher alkali earth content of titanomagnetite compared to ilmenite enabled the production of slags with lower $\mathrm{FeO}$ content, for example. Titaniferous magnetite ores are also not associated with $U$ and Th, both of which concentrate in the waste streams during pigment production and contribute significantly to environmental challenges.

Efficient recovery of titanium from titaniferous magnetite ores continues to be an unrealised opportunity, despite significant global occurrences of titaniferous magnetite deposits. The pilot test demonstrated that fluxless smelting in an open-arc furnace could be the first step to unlocking the full value of these deposits. The current study shows that there is no apparent technical barrier to producing high-titania slags from titaniferous magnetite. The ultimate goal of effective comprehensive processing of titaniferous magnetite ores is, however, not a trivial challenge; while both iron and vanadium offer great economic incentives to process these ores, titania remains an unrealised opportunity.

As smelting is an energy-intensive process, integration of renewable energy and pre-treatment options is critical. Titania feedstocks are not particularly scarce and thus the combined incentives of iron, vanadium and titanium need to be realised via state-of-the-art smelting practices to offer an economically competitive process. Optimisation of vanadium recovery and the integration of renewable energy and hydrogen opportunities linked to a
DC open-arc smelting furnace are of particular interest for future work. Future work will include assessing the slag phase chemistry for vanadiumbearing titaniferous magnetite in the context slag upgrading potential, especially minimising the formation of spinel phases, as well as evaluating the impact of minor element impurities in the slag quality and the associated techno-economic challenges.

\section{CONCLUSION}

Pilot smelting of titaniferous magnetite under fluxless smelting conditions demonstrated that the slag produced from complex titaniferous ore is similar to furnace slags produced from ilmenite feedstocks. The higher alkali earth content of titanomagnetite compared to ilmenite enabled the production of slags with lower $\mathrm{FeO}$ content, resulting in high iron recoveries.

The pilot slags follow the $\mathrm{M}_{3} \mathrm{O}_{5}$ stoichiometry, while the phase chemical evaluation confirmed remarkably low levels of $\mathrm{FeO}$ in the $\mathrm{M}_{3} \mathrm{O}_{5}$ phase, which is consistent with the chemical composition of the high-titania slags produced during the test. The deterministic nature of the $\mathrm{FeO}-\mathrm{TiO}_{2}$ relationship suggests that for a given degree of reduction and the impurity content of the titaniferous ore and reductant, it is feasible to predict the composition of the slag. Titaniferous magnetite deposits vary widely in composition, and this relationship is a useful tool for future evaluations.

The pilot test demonstrated that it is feasible to process low-grade titaniferous ore in a DC open-arc smelter to produce a high-grade slag. At the same time, significant opportunities exist to optimise the feed composition, energy consumption, operating temperature and slag chemistry to optimally extract iron, vanadium and titanium.

\section{ACKNOWLEDGEMENTS}

The paper is published with permission and financial support from Mintek. The data presented in this paper form part of a master's thesis titled "Feasibility of fluxless smelting of titaniferous magnetite ore in a pilot-plan open-arc DC furnace". ${ }^{26}$

\section{OPEN ACCESS}

This article is licensed under a Creative Commons Attribution 4.0 International License, which permits use, sharing, adaptation, distribution and reproduction in any medium or format, as long as you give appropriate credit to the original author(s) and the source, provide a link to the Creative Commons licence, and indicate if changes were made. The images or other third party material in this article are included in the article's Creative Commons licence, unless indicated otherwise in a credit line to the material. If material is not included in the ar- 
ticle's Creative Commons licence and your intended use is not permitted by statutory regulation or exceeds the permitted use, you will need to obtain permission directly from the copyright holder. To view a copy of this licence, visit http://creativecom mons.org/licenses/by/4.0/.

\section{REFERENCES}

1. M. Gous, J. South Afr. Inst. Min. Metall. 106, 379 (2006).

2. G.E. Williams and J.D. Steenkamp, South African Pyrometallurgy 2006, ed. R.T. Jones (Johannesburg: South African Institute of Mining and Metallurgy, 2006), pp. 5-8.

3. T. Rosenqvist, Trans. Tech. Univ. Kosice 2, 40 (1992).

4. F. Habashi, Steel Times Int. 34, 48 (2010).

5. C. Li, B. Liang, L. Hong Guo, and Z.B. Wu, Miner. Eng. 19, 1430 (2006)

6. E. Hukkanen and H. Walden, Int. J. Miner. Process. 15, 89 (1985).

7. W.G. Fu and H.E. Xie, Steel Res. Int. 82, 501 (2011).

8. W. Steinberg, W. Geyser, and J. Nell, J. South Afr. Inst. Min. Metall. 111, 705 (2011).

9. B.F. Kelly, in Australas. Min. Metall. Sir Maurice Mawby Meml. Vol. (2nd Ed.). (Monograph Ser. (Australasian Inst. Min. Metall. 19). (1993). Park. Vic. AusIMM. (Australasian Institute of Mining and Metallurgy, Victoria, Australia, 1993), pp. 348-353.

10. U.S. Geological Survey, United States Geol. Surv. 200 (2020).

11. J. Gambogi and S.J. Gerdemann, in Rev. Extr. Process. Prop. Appl. React. Met. (TMS The Minerals, Metals \& Materials Society, San Diego, 2013), pp. 175-210.

12. J.R. Fisher, in Heavy Miner. 1997 (1997), pp. 207-218.
13. D. Filippou and G. Hudon, JOM 61, 36 (2009).

14. K.K. Sahu, T.C. Alex, D. Mishra, and A. Agrawal, Waste Manag. Res. 24, 74 (2006).

15. R.P. Fischer, U.S. Geol. Surv. Prof. Pap. 926-B, 1 (1975).

16. B. Rohrmann, J. South Afr. Inst. Min. Metall. 85, 141 (1985)

17. P.R. Taylor, S.A. Shuey, Edgar E. Vidal, W. Wang, and J. C. Gomez, in 2005 SME Annu. Meet. 1 (2005).

18. H. Sun, J. Wang, X. Dong, and Q. Xue, Metal. Int. 17, 49 (2012).

19. P.C. Pistorius, J. South Afr. Inst. Min. Metall. 108, 35 (2008).

20. R.G. Cawthorn, S. Barnes, C. Ballhaus, and K.N. Malitch, in Econ. Geol. 100th Anniv. Vol. (Society of Economic Geologists, 2005), pp. 215-249.

21. M. Guéguin and F. Cardarelli, Miner. Process. Extr. Metall. Rev. 28, 1 (2007).

22. H. Consensi and C. Kotze, Journace South Afr. Inst. Min. Metall. 120, 121 (2020).

23. H. Burger, D. Bessinger, and S. Moodley, in 7th Int. Heavy Miner. Conf. "What Next" (The Southern African Institute of Mining and Metallurgy, 2009), pp. 187-194.

24. J.H. Zietsman and P.C. Pistorius, J. South Afr. Inst. Min. Metall. 105, 229 (2005)

25. S.K. Gilman, and R.K.A. Taylor, in Int. Heavy Miner. Conf. (AusIMM, Fremantle, 2001), pp. 18-19.

26. I.J. Geldenhuys, Feasibility of Fluxless Smelting of Titaniferous Magnetite Ore in a Pilot-Plan Open-Arc DC Furnace, Stellenbosch University, 2020.

Publisher's Note Springer Nature remains neutral with regard to jurisdictional claims in published maps and institutional affiliations. 